\title{
Voltage-operated calcium channels in male germ cells
}

\author{
Suchitra Jagannathan ${ }^{1}$, Stephen J. Publicover ${ }^{1}$ \\ and Christopher L. R. Barratt ${ }^{2 *}$ \\ ${ }^{1}$ School of Biosciences, University of Birmingham, Birmingham B15 2TT, UK; and \\ ${ }^{2}$ Reproductive Biology and Genetics Research Group, Birmingham Women's Hospital, \\ Birmingham B15 2TG, UK
}

\begin{abstract}
The acrosome reaction is a key event in fertilization. Current models for induction of the acrosome reaction incorporate a necessary influx of $\mathrm{Ca}^{2+}$, which is mediated by agonistinduced gating of ion channels in the sperm plasma membrane. The difficulty of applying electrophysiological techniques to spermatozoa has severely hampered studies on the expression of functional ion channels in these cells. However, during the last few years, a combination of molecular and physiological techniques (applied to immature spermatogenic cells) has elucidated both the expression of $\mathrm{Ca}^{2+}$ channels in male germ cells and their role in induction of the acrosome reaction. It now appears that a range of voltageoperated $\mathrm{Ca}^{2+}$ channels, similar to those that occur in somatic cells, is expressed in spermatozoa. Male rodent germ cells express a low-voltage activated (T-type) channel that is regulated by membrane potential and provides the primary $\mathrm{Ca}^{2+}$ influx mechanism in zona pellucida-stimulated spermatozoa. In human spermatozoa, similar channels are apparently expressed, but their function in induction of the acrosome reaction has yet to be established. A range of other, high voltage-activated channels also appear to be present in rodent and human spermatozoa, but their roles are not yet known. In this review, the structure and characteristics of voltage-operated $\mathrm{Ca}^{2+}$ channels are outlined and the evidence for their expression and function in male germ cells is assembled and discussed.
\end{abstract}

Sexual reproduction in mammals is achieved by the fusion of a spermatozoon with the oocyte. The spermatozoon must penetrate the egg vestments and bind to the oolemma before gamete fusion can occur. A pivotal event in this process is the acrosome reaction wherein the acrosome, a secretory vesicle in the apical region of the spermatozoon, fuses with the overlying plasma membrane. This fusion results in secretion of the acrosomal contents and also incorporation of the inner acrosomal membrane into the plasmalemma. These processes are believed to be important for penetration of the zona pellucida and sperm-oocyte fusion (Ward and Kopf, 1993).

\section{Agonist-induced $\mathrm{Ca}^{2+}$ signalling in spermatozoa and male infertility}

Acrosome reaction is a secretory event triggered as the spermatozoon approaches the egg (Yanagimachi, 1994). Although a number of intracellular messenger systems have been implicated and the biochemistry of the acrosome reaction is complex (Ward and Kopf, 1993; Breitbart and Spungin, 1997), it appears that gating of $\mathrm{Ca}^{2+}$ channels and consequent $\mathrm{Ca}^{2+}$ influx plays a central role. In several

*Correspondence

Email: c.l.barratt@bham.ac.uk mammals, a sustained increase in $\left[\mathrm{Ca}^{2+}\right]_{i}$, dependent upon influx of extracellular $\mathrm{Ca}^{2+}$, is induced directly by solubilized zona pellucida. The initial phase of zona pellucida-induced $\mathrm{Ca}^{2+}$ influx appears to require activation of voltage-operated calcium channels (VOCCs). Organic and inorganic antagonists of VOCCs, including 1,4-dihydropyridines (DHPs), a class of drugs specific for these channels, inhibit both the zona pellucida-induced $\mathrm{Ca}^{2+}$ signal and the consequent acrosome reaction (Florman et al., 1998; Darszon et al., 1999; Publicover and Barratt, 1999). Progesterone is the only other well-characterized agonist of the acrosome reaction. In a similar manner to the zona pellucida, progesterone causes a rapid and transient increase in $\left[\mathrm{Ca}^{2+}\right]_{i}$, accompanied by depolarization, followed by a sustained $\left[\mathrm{Ca}^{2+}\right]_{\mathrm{i}}$ response. Progesterone-induced acrosome reaction is also blocked by DHPs, but the role of VOCCs in this process is disputed (Publicover and Barratt, 1999).

Although sperm dysfunction is the single most common cause of human infertility (Hull et al., 1985; Irvine, 1998), very little is known about the cellular, molecular or genetic causes of this pathology. Defective acrosome reaction and, by implication, $\left[\mathrm{Ca}^{2+}\right]_{i}$ signalling is a common feature of male factor infertility (Barratt and Publicover, 2001). For example, Liu et al. (2001) calculated that approximately $25 \%$ of infertile men with normal semen parameters show disordered zona pellucida-induced acrosome reaction 
(a) Unidentified channel

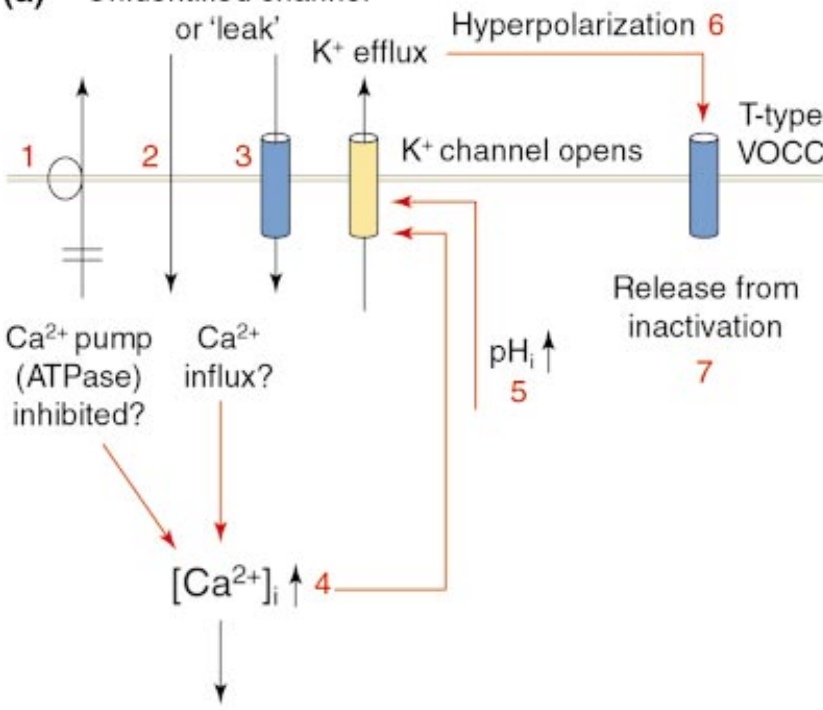

Other capacitation events?

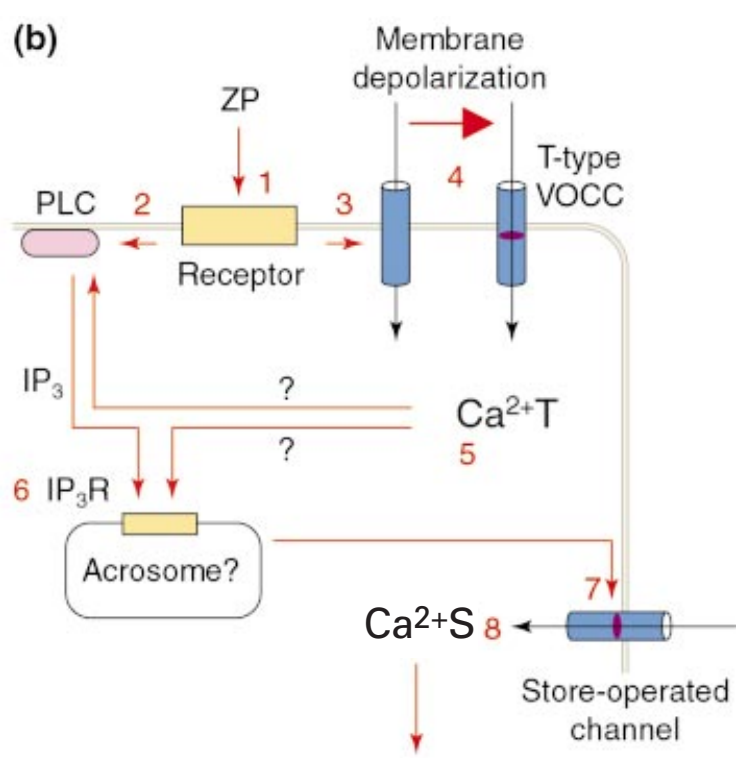

Acrosome reaction

Fig. 1. Regulation and activation of voltage-operated calcium channels (VOCCs) during capacitation and induction of the acrosome reaction by zona pellucida in mammalian spermatozoa. Red arrows show causative links between components of the pathways. Red numbers refer to specific components of the pathways explained below. Blue cylinders in the membrane represent $\mathrm{Ca}^{2+}$ channels or cation channels carrying inward ion flux. Yellow cylinders represent $\mathrm{K}^{+}$channels. Yellow boxes represent receptor molecules. The pink box represents phospholipase C (PLC). (a) Possible regulation of the T-type voltage-operated $\mathrm{Ca}^{2+}$ channels of mammalian spermatozoa by membrane potential. During capacitation, one or more of the following: (1) reduced $\mathrm{Ca}^{2+}$ efflux due to inhibition of the Ca ${ }^{2+}$ ATPase pump; (2) increased leakage of $\mathrm{Ca}^{2+}$ across the bilayer due to instability caused by removal of cholesterol; and (3) increased $\mathrm{Ca}^{2+}$ influx due to the opening of an unidentified channel, result in increased $\left[\mathrm{Ca}^{2+}\right]_{i}$ (4). Cytoplasmic alkalinization (5) is also known to occur during capacitation. Either or both $\left[\mathrm{Ca}^{2+}\right]_{\mathrm{i}}$ and $\mathrm{pH}_{\mathrm{i}}$ may regulate one or more types of $\mathrm{K}^{+}$channel in the sperm plasma membrane, causing hyperpolarization (6) of the membrane potential. This hyperpolarization releases the T-type voltage-operated Ca ${ }^{2+}$ channels from inactivation (7) such that they are competent to respond to a stimulus provided by zona pellucida. (b) Probable participation of T-type VOCCs and store-operated $\mathrm{Ca}^{2+}$ channels in induction of the acrosome reaction by zona pellucida. Binding of zona pellucida (ZP) to its receptor (1) activates both PLC (2) and an unidentified cation channel (3). Opening of the cation channel enables cation influx, causing depolarization (4) of the plasma membrane, resulting in activation of T-type voltage-operated $\mathrm{Ca}^{2+}$ channels. The resulting brief $\mathrm{Ca}^{2+}$ influx generates a transient increase in $\left[\mathrm{Ca}^{2+}\right]_{i}\left(\mathrm{Ca}^{2+} \mathrm{T} ; 5\right)$. Inositol trisphosphate $\left(\mathrm{IP}_{3}\right)$, generated by the activated phospholipase $\mathrm{C}_{\text {, binds }} \mathrm{IP}_{3}$ receptors, probably on the acrosome (6), causing release of stored $\mathrm{Ca}^{2+}$. Upon emptying of the store, store-operated channels in the plasma membrane open (7), allowing influx of $\mathrm{Ca}^{2+}$ and causing a sustained increase in $\left[\mathrm{Ca}^{2+}\right]_{i}\left(\mathrm{Ca}^{2+} S\right.$; 8), which leads to the acrosome reaction. $\mathrm{Ca}^{2+} \mathrm{S}$ is never generated unless $\mathrm{Ca}^{2+} \mathrm{T}$ occurs first, indicating that the $\mathrm{Ca}^{2+}$ that enters through the T-type VOCCs plays a part in events leading to opening of the store-operated channels. Possible sites of action are at the activation of PLC or at the activation of the IP 3 receptor (both labelled with a question mark).

(characterized by normal zona pellucida binding but failure to undergo acrosome reaction and penetrate the zona pellucida). Furthermore, several studies have shown that failure to generate a calcium influx in response to progesterone is strongly associated with sperm dysfunction (Oehninger et al., 1994) and reduced fertilization success at in vitro fertilization (Krausz et al., 1995). Currently, the specific defects in men who fail to generate a calcium signal are unknown. Failure to generate a calcium signal could be the result of several factors, including failure of agonist binding or defective $\mathrm{Ca}^{2+}$ signalling machinery. Impaired expression or function of VOCCs is a likely cause. The function and regulation of VOCCs in the working of the normal cell needs to be understood before their potential role in male factor infertility can be assessed. Elucidation of the nature of VOCCs in male germ cells is a vital first step in the development of effective rational therapy.

The difficulty of obtaining testicular biopsies and spermatogenic cells from fertile donors has proved an impediment to molecular and electrophysiological research on the VOCCs of human male germ cells, such that our knowledge is rudimentary. However, there has been considerable progress in characterizing the VOCCs in spermatozoa and male germ cells of other mammals, particularly in the activation of rodent spermatozoa by zona pellucida. The probable regulation and activation of VOCCs during capacitation and induction of the acrosome reaction by zona pellucida in mammals are summarized (Fig. 1). Most 
of the relevant data, particularly on the response to zona pellucida, derive from studies in mice. This review discusses the status of VOCCs in spermatozoa (primarily those of humans and rodents) as determined from pharmacological, physiological and molecular studies, and attempts to place these channels in the context of the diversity of VOCCs that has been described in somatic cells. The role and regulation of VOCCs in animal and human spermatozoa are also discussed.

\section{Voltage-operated $\mathrm{Ca}^{2+}$ channels}

\section{Physiology and pharmacology}

On the basis of their biophysical and pharmacological properties, VOCCs have been classified into high voltage activated (HVA) and low voltage activated (LVA) channels.

HVA channels. HVA channels are so-called because of their requirement for a relatively large depolarization (positive shift of the membrane potential from its resting value, for example, from -80 to $-30 \mathrm{mV}$ ) to induce channel opening. Typically, HVA channels open at voltages $\geqslant-30$ $\mathrm{mV}$. On the basis of biophysical and pharmacological characteristics, HVA channels have been divided into $L, N$, $\mathrm{P}, \mathrm{Q}$ and $\mathrm{R}$ types. Consistent differences have been observed in rates and voltage-dependence of activation, inactivation and deactivation among these types of channel (see Box 1 for an explanation of these processes) such that each type has its own 'signature' (Randall, 1998). The genuine nature of these distinctions is confirmed by the discrete pharmacological sensitivity of each of the HVA channel subtypes (Randall, 1998; Tsien et al., 1998). L-type channels show a particular sensitivity to DHPs, whereas $\mathrm{N}$ type channels are uniquely sensitive to $\omega$-conotoxin GVIA (from the cone snail Conus geographus L.). P, Q and R channels can be separated by their differential sensitivities to $\omega$-conotoxins and $\omega$-agatoxins (from the funnel web spider Agelenopsis aptera) (Mintz, 1994; Randall, 1998).

LVA channels. LVA channels activate in response to relatively modest depolarizations (typically $\geqslant-60 \mathrm{mV}$ ) and are characterized by the lowest single channel conductance of all the VOCCs and by the transient nature of their wholecell current. Typically LVA channels inactivate within 50-100 ms in response to a step voltage change (Fig. 2b). Selective pharmacological modulation of T-type channels continues to present a problem. Nickel $\left(\mathrm{Ni}^{2+}\right)$, mibefradil and amiloride have been used to discriminate T-type channels from the HVA channels. Mibefradil exerts a potent inhibitory effect on T-type $\mathrm{Ca}^{2+}$ currents (Mishra and Hermsmeyer, 1994; Todorovic and Lingle, 1998) and has been used as a probe for the involvement of T-type channels in cellular responses, including those of spermatozoa. However, at higher concentrations, mibefradil can antagonize HVA Ca ${ }^{2+}$ currents (Martin et al., 2000; Wu et al., 2000) and in some cells studies show little selectivity between LVA and HVA channels. Similarly, low ( $\mu$ mol $\mathrm{I}^{-1}$ ) concentrations of $\mathrm{Ni}^{2+}$ have been used to block T-type currents selectively in several types of cell, for example sino-atrial nodal cells and sensory neurones (Todorovic and Lingle, 1998), as well as spermatozoa. However, sensitivity to $\mathrm{Ni}^{2+}$ has been observed occasionally in HVA channels, as has low $\mathrm{Ni}^{2+}$ sensitivity of T-type currents in neuronal cells (Zamponi et al., 1996). Therefore, the best that can be said is that there is a range of semi-selective compounds available, none of which offer selectivity such that they can be regarded as diagnostic of T-type channels.

\section{Structure}

The main structural constituent of all VOCCs is the single, pore-forming $\alpha_{1}$ subunit. This subunit is the primary determinant of the biophysical and pharmacological variation among VOCCs. It is composed of four homologous domains (Fig. 2a), which are interconnected by cytoplasmic linker regions. Each domain is made up of six transmembrane helices, S1-S6. Between the S5 and S6 segments in each domain there is a non-helical P-loop. The four P-loops are believed to line the channel pore (Catterall, 1995).

Ten $\alpha_{1}$ subunit genes, $\left(\alpha_{1 \mathrm{~A}-\text { I }}\right.$ and $\left.\alpha 1_{\mathrm{S}}\right)$ have been identified thus far by molecular cloning, mostly in neuronal and cardiac tissues. Of these, $\alpha_{1 A}, \alpha_{B}, \alpha_{C}, \alpha_{D}, \alpha_{E}, \alpha_{F}$ and $\alpha_{1 S}$ all appear to form HVA channels. Some of these subunits, when expressed as recombinant channels, closely resemble one of the biophysical-pharmacological subtypes described above. $\alpha_{1 \mathrm{~B}}$ is clearly $\mathrm{N}$-type and $\alpha_{1 \mathrm{C}}, \alpha_{1 \mathrm{D}}$ and $\alpha_{1 \mathrm{~S}}$ are all types of L-channel. $\alpha_{1 \mathrm{~A}}$ and $\alpha_{1 \mathrm{E}}$ probably form P/Q- and Rtype channels, respectively, although this has yet to be firmly established. $\alpha_{1 \mathrm{G}}, \alpha_{1 \mathrm{H}}$ and $\alpha_{1 \text {, }}$ have been discovered relatively recently (Perez-Reyes et al., 1998; Williams et al., 1999; Monteil et al., 2000a) and constitute the LVA channel family. These subunits vary in their biophysical properties (activation, inactivation, deactivation; Box 1) and in their pharmacological characteristics. For instance, $\alpha_{1 \mathrm{H}}$ is considerably more $\mathrm{Ni}^{2+}$-sensitive than $\alpha_{1 \mathrm{G}}$ or $\alpha_{11}$ (Lacinová et al., 2000). Members of the LVA family of $\alpha_{1}$ gene products are particularly subject to alternative splicing, which leads to a considerable increase in functional diversity beyond that derived from the three genes.

In HVA channels, the $\alpha_{1}$ subunit is associated with $\beta, \alpha_{2}-$ $\delta$, and possibly $\gamma$ subunits (Birnbaumer et al., 1998; Walker and De Waard, 1998). These auxiliary subunits regulate expression and biophysical characteristics of the $\alpha_{1}$ subunit with which they associate. However, the domain within HVA $\alpha_{1}$ subunits that interacts with the $\beta$ subunit (Fig. 2 ) is not present in LVA channels. Although modest effects of auxiliary subunits on T-type channels have been reported (Dolphin et al., 1999; Gao et al., 2000), most data on expression of recombinant channels indicate that LVA channels can function independently, without associating with any of the auxiliary subunits (Perez-Reyes et al., 1998; Lacinová et al., 2000). 


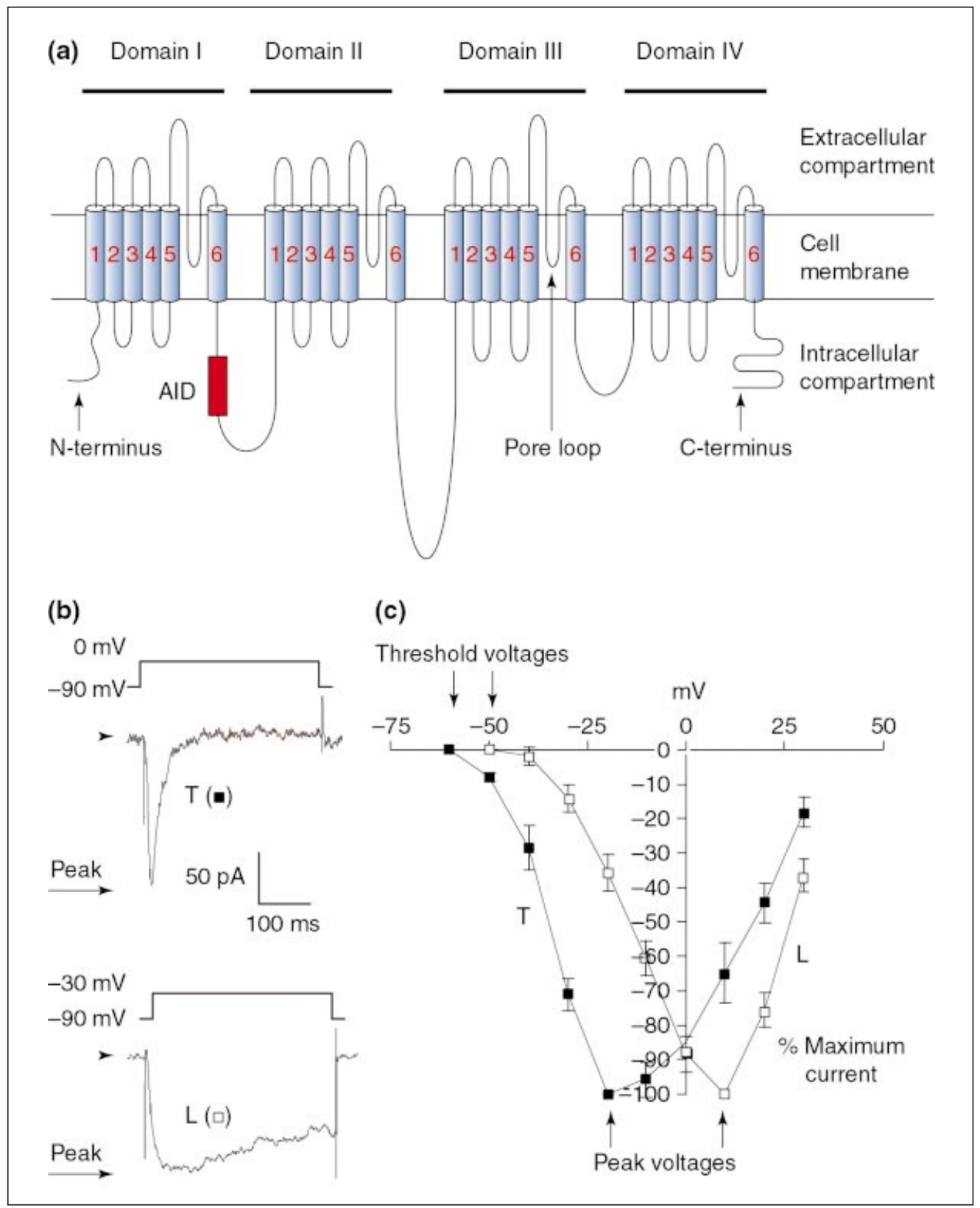

Fig. 2. Structure and functional characteristics of voltage-operated $\mathrm{Ca}^{2+}$ channels (VOCCs). (a) Putative structure of a VOCC $\alpha_{1}$ subunit. All VOCCs are made up of four repeating domains numbered I-IV from the $\mathrm{N}$-terminus. Each domain is composed of six membrane-spanning alpha-helical regions (blue cylinders) numbered 1-6 (labelled in red). The membrane-spanning regions are interspersed by linkers that extend alternately outside and inside of the membrane. The four 5-6 linkers each include an intramembrane stretch called the pore loop. The four pore-loops are believed to extend into the pore (which is lined by helices 5 and 6 in each domain) and to contribute to selectivity. Transmembrane helix 4 in each domain includes a high proportion of charged residues and is believed to act as a voltage sensor. The I-II (intracellular) linker includes sites at which the $\alpha_{1}$ subunit interacts with the $\beta$ subunit (alpha interaction domain (AID) shown as a red box) and sites at which channel activity can be regulated by phosphorylation (Dolphin, 1998; Dunlap and Ikeda, 1998; Zamponi and Snutch, 1998). The sequence for interaction with the $\beta$ subunit is not present on the I-II linker of low voltage activated (LVA) $\alpha 1$ subunits (Lacinová et al., 2000). (b) T- and L-type currents recorded by the whole-cell variant of the patch clamp technique, in which the record shows the summed activity of a population of channels (see Box 1). The upper trace shows a fast-inactivating T-type (LVA) current. Upon application of a depolarizing pulse to the cell (from -90 to $0 \mathrm{mV}$; marker above the trace) the inward $\mathrm{Ca}^{2+}$ current 


\section{Voltage-operated $\mathrm{Ca}^{2+}$ channels in male germ cells}

\section{Molecular studies}

As spermatozoa are believed to be transcriptionally inactive, studies of gene expression in these cells have been carried out primarily on RNA isolated from progenitor spermatogenic cells (see Table 1). Transcripts for a number of HVA channels encoding $\alpha_{1 \mathrm{~A}}, \alpha_{1 \mathrm{~B}}, \alpha_{1 \mathrm{C}}, \alpha_{1 \mathrm{D}}$ and $\alpha_{1 \mathrm{E}}$ subunits have been detected by PCR using total RNA from mouse seminiferous tubules (Liévano et al., 1996). RT-PCR on RNA from purified mouse spermatogenic cells detected primarily $\alpha 1_{\mathrm{E}}$ transcript; $\alpha_{1 \mathrm{~A}}$ and $\alpha_{1 \mathrm{C}}$ transcripts were present in small amounts (Lievano et al., 1996; Espinosa et al., 1999). Benoff and colleagues have consistently detected transcripts for $\alpha_{1 C}$ in rat and human testis (Goodwin et al., 1997, 1998). In situ RT-PCR of rat testis sections indicated that testis-specific $\alpha_{1 C}$ transcripts were present at all stages of the germ cell lineage (Goodwin et al., 1998). In addition, Goodwin et al. (2000) reported the detection of message for $\alpha_{1 C}$ in RNA from mature ejaculated human spermatozoa.

Detection of LVA channels has proved problematic. Using a series of primers against various regions of the LVA $\alpha_{1 G}$ subunit, Jacob and Benoff (2000) detected only transcripts encoding for domain IV and the C-terminus in rat testis RNA. No PCR products were generated with cDNA from human spermatozoa (Jacob and Benoff, 2000). Espinosa et al. (1999), using primers directed against the Ctermini of $\alpha_{1 \mathrm{G}}$ and $\alpha_{1 \mathrm{H}}$, obtained PCR products from mouse spermatogenic cell cDNA. Son et al. (2000) used degenerate primers on cDNA from human testicular biopsies to obtain a 489 bp fragment of $\alpha_{1 \mathrm{H}}$, but neither $\alpha_{1 \mathrm{G}}$ nor $\alpha_{11}$ was detected. Recently, the full-length sequences of both $\alpha_{1 \mathrm{G}}$ and $\alpha_{1 \mathrm{H}}$ LVA channels from human testicular cDNA were obtained by amplifying a series of overlapping PCR products. Both channels are present in multiple isoforms. These transcripts have also been observed in human male germ cells (Jagannathan et al., 2000a,b, in press).

Immunocytochemical studies using anti-peptide antibodies raised to cytosolic domains of rat brain VOCCs have shown the presence and regional localization of $\alpha_{1 \mathrm{~A}}$, $\alpha_{1 \mathrm{~B}}, \alpha_{1 \mathrm{C}}$ and $\alpha_{1 \mathrm{E}}$ subunit proteins on mouse spermatozoa (Westenbroek and Babcock, 1999; Wennemuth et al., 2000). All of the four channel subunits generate a punctate staining pattern. Intriguingly, all four of these channel proteins have distinct localization patterns, indicating specialization of function. Serrano et al. (1999) have also detected $\alpha_{1 \mathrm{~A}}$ and $\alpha_{1 \mathrm{C}}$ in mouse spermatogenic cells, the protein being detectable in the cytoplasm as well as at the cell surface. No specific binding, in mouse spermatogenic cells or spermatozoa, was detected with antibodies to $\alpha_{1 \mathrm{~B}}$ or $\alpha_{1 \mathrm{D}}$ (Serrano et al., 1999). Goodwin et al. (1997) showed that an antibody directed against rabbit $\alpha_{15}$, probably detecting the $\alpha_{1 \mathrm{c}}$ protein, labelled the postacrosomal region of human spermatozoa. Immunolocalization of $\alpha_{1 \mathrm{~A}}, \alpha_{1 \mathrm{~B}}$, and $\alpha_{1 \mathrm{E}}$ proteins have also been shown in rat Sertoli cells and within the seminiferous epithelium, peritubular and interstitial tissues, indicating a role at the blood-testis barrier (Fragale et al., 2000).

The only study to date on expression of VOCC auxiliary subunits was carried out by Serrano et al. (1999), who reported detection of all four types of VOCC $\beta$ subunit by RT-PCR of mouse germ cell mRNA. Use of specific antibodies also identified all $\beta$ subunits except b4 in spermatogenic cells and spermatozoa, and staining in the spermatozoon showed regional localization.

\section{$\left[\mathrm{Ca}^{2+}\right]_{i}$ responses to depolarization}

In most cells, the resting membrane potential $\left(E_{\mathrm{m}}\right)$ is determined primarily by the equilibrium potential for $\mathrm{K}^{+}\left(E_{\mathrm{K}}\right.$; see Box 2). Therefore, an increase in $\left[\mathrm{K}^{+}\right]_{\mathrm{O}}$ and the consequent positive shift of $E_{\mathrm{K}}$ can be used to activate VOCCs and processes mediated by VOCCs. Several studies have addressed the response of $\left[\mathrm{Ca}^{2+}\right]_{\mathrm{i}}$ in mature spermatozoa to $\mathrm{K}^{+}$-induced depolarization. Spermatozoa of the sea urchin Lytechinus pictus show an increase in $\left[\mathrm{Ca}^{2+}\right]_{\mathrm{i}}$ in response to $\mathrm{K}^{+}$depolarization, provided that they have already undergone a valinomycin-induced hyperpolarization (see Box 2).

(downward deflection of the trace) reaches a peak (arrow) and then rapidly decays as the channels inactivate, returning to resting levels (arrowhead at the start of the trace) within $100 \mathrm{~ms}$. The lower trace shows a more slowly inactivating L-type current, induced by a voltage step from -90 to $-30 \mathrm{mV}$ (marker above the trace). The inward $\mathrm{Ca}^{2+}$ current reaches a peak (arrow) and decays less than halfway back towards resting levels (arrowhead at the start of the trace) during the duration of the depolarizing pulse (400 ms). Scale bars show $50 \mathrm{pA}$ and $100 \mathrm{~ms}$ and refer to both traces. Both currents were recorded from osteoblasts. Peak (arrows) indicates the maximum current used for constructing current voltage relationships (see Box 1). (c) Current-voltage relationships for whole-cell T-currents $(\boldsymbol{\square})$ and L-currents ( $\square$ ) of the type shown in (b). These relationships were constructed by applying a series of voltage steps from a resting membrane voltage ( $-90 \mathrm{mV})$ to various values of membrane potential, to obtain a 'family' of currents. The maximum current evoked by each step (see arrows in (b)) was then measured and plotted against the voltage to which the membrane potential was stepped to evoke that current. For each current type, data from five cells have been normalized (by expressing as percentages of the maximum current) and plotted as mean \pm SEM. The inward $\mathrm{Ca}^{2+}$ current is plotted below the horizontal axis, consistent with the downward deflection of the current trace for an inward current (see (b) and Box 1). Plots of this type are characteristically biphasic for VOCCs, increasing from a 'threshold' voltage, at which the channels are just activated (see Box 1), to a peak value and then decreasing in amplitude at more positive values. The increase in current amplitude that occurs in the voltage range between the threshold and the peak reflects recruitment of an increasing proportion of the population of channels as the depolarizing steps become larger (see Box 1). Peak current occurs close to the value at which all the channels open. The reduced current amplitude that is seen upon steps to more positive voltages reflects the reduced driving force for ion influx as the voltage begins to approach the equilibrium potential for $\mathrm{Ca}^{2+}$ (see Box 2). Osteoblasts, from which these recordings were made, express $\alpha_{1 \mathrm{C}}$, $\alpha_{1 \mathrm{D}}$ and $\alpha_{1 \mathrm{G}}$ subunits (Gu et al., 1999) but not $\alpha_{1 \mathrm{H}}$ (Y. Gu, S. Jagannathan, T. Snow and S. J. Publicover, unpublished). 


\section{Box 1. Biophysical characteristics of voltage-operated $\mathrm{Ca}^{2+}$ channels}

Classification of voltage-operated calcium channels (VOCCs) is based upon pharmacological sensitivity, relative permeability to $\mathrm{Ca}^{2+} / \mathrm{Ba}^{2+}$ and biophysical characteristics. Diagnostic biophysical features include characteristics of activation, characteristics of inactivation and rate of deactivation (Randall, 1998).

Activation is the voltage-activated transition of a channel from the closed to the open state that occurs in response to depolarization of membrane potential $\left(E_{\mathrm{m}}\right)$. The probability of opening for any individual channel is a function of $E_{\mathrm{m}}$. In a population of channels, there is a sigmoid relationship between membrane voltage and the proportion of open channels, with a threshold value below which the channels remain closed and a saturation value above which virtually all channels will open. The voltage range between threshold and saturation is characteristic of the type of channel. Low voltage-activated (LVA) and high voltage-activated (HVA) channels are clearly separable in this way and there are also small differences between channels within the two families. The latency of channel activation in response to a depolarizing step is also variable. In whole-cell clamp records, this results in a 'ramp' at the start of the whole-cell current as individual channels are recruited into the open population (see figure).

Inactivation is the process by which channels in the open configuration spontaneously adopt a non-permeable state despite maintenance of $E_{\mathrm{m}}$ at a value sufficient to permit channel opening. In whole-cell records, this adoption of a non-permeable state appears as a decay of current amplitude during the depolarizing pulse that is used to activate the channels. There appear to be three types of VOCC inactivation, including a $\mathrm{Ca}^{2+}-$ calmodulin mediated effect, a voltage-mediated effect and a poorly understood slow form of inactivation (Stotz and Zamponi, 2001). The rapid inactivation of LVA channels is voltage-induced, depolarization itself causing a structural rearrangement of the channel. Both the rate of inactivation of open channels and the extent of inactivation (proportion of channels that adopt the inactivated state) are voltage-dependent. The 'inactivated' state is different from the normal closed state, and inactivated channels do not re-open without first returning to the closed state, which requires a return of $E_{\mathrm{m}}$ to a more negative voltage (see figure).

Deactivation is the process by which channels that have opened in response to depolarization (but have not yet inactivated) return to the closed state upon repolarization of $E_{\mathrm{m}}$. When a voltage pulse terminates and $E_{\mathrm{m}}$ returns to more negative values, there is a brief increase in current amplitude before deactivation (called the tail current; see figure) as a result of the increase in inward driving force on the charge carrier. In whole-cell records, the time course of decay of the tail current reflects the distribution of latencies for deactivation of the individual channels. This time course is particularly slow in T channels and is one of the diagnostic features of this type of channel.
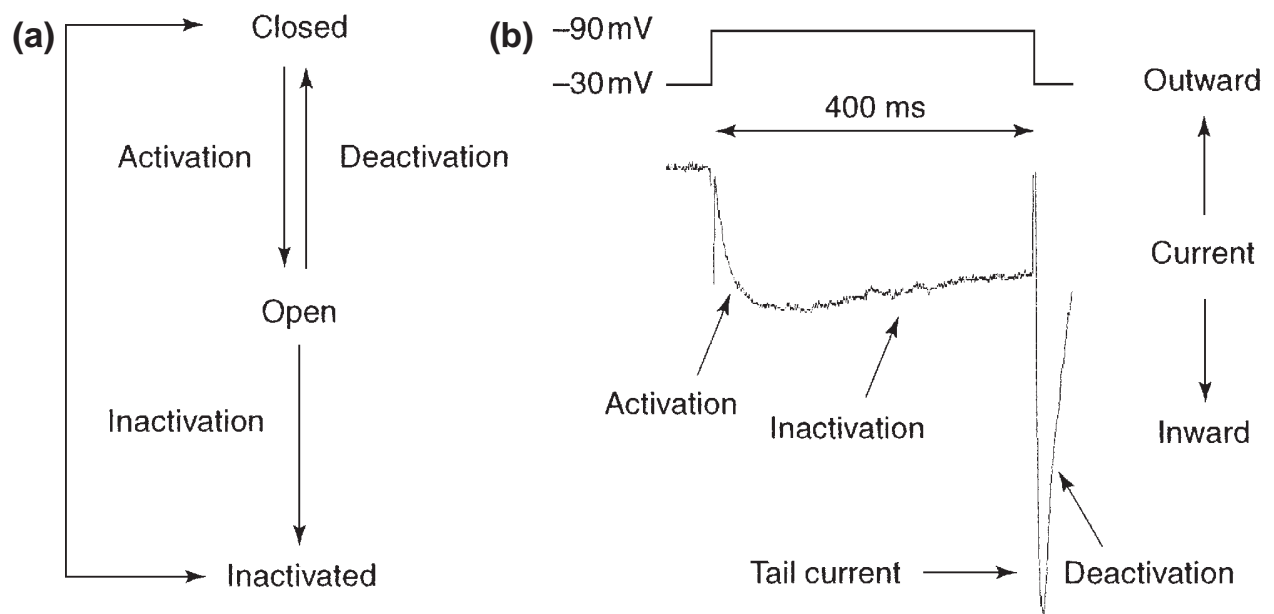

(a) Simple model for transition of a voltage-operated channel between states, based upon models for inactivation of voltage-operated $\mathrm{Na}^{+}$ channels, in which there may be several closed states, only one of which can undergo the transition to the open state. When the membrane is at resting potential, the channels are closed. Upon depolarization, a proportion of channels undergo activation to adopt the open state (see above) and may then 'flicker' between open and closed states. While the membrane is depolarized, open channels can become inactivated. From the inactivated state, the channels do not re-open but they can return to the closed state upon repolarization of $E_{\mathrm{m}}$ to sufficiently negative values. It is not clear whether channels can pass directly between closed and inactivated states (shown by the long, double-headed arrow that bypasses the open state) but this seems likely. Those channels that are still open at the end of a period of depolarization return to the closed state by deactivation. (b) Whole-cell record from a cell expressing L-type VOCCs. This type of record shows the summed currents from a large number of channels (see Fig. 2b). Although transitions between the various channel states are rapid and appear as steps on single channel records, in whole-cell records, the kinetics of the transition of the population of channels between one state and another can be visualized and measured. Upon application of a $400 \mathrm{~ms}$ depolarization from -90 to $-30 \mathrm{mV}$ (shown by the marker above the trace), a population of $\mathrm{L}$ channels undergoes activation, which, in this case, takes approximately $100 \mathrm{~ms}$ to reach completion. A proportion of these open channels (approximately 25\%) then inactivate during the pulse (duration = $400 \mathrm{~ms}$ ), which appears as a slow decay in the current amplitude. Upon repolarization of $E_{\mathrm{m}}$ a large tail current is seen that returns to zero as the channels deactivate. This recording was made in the presence of the VOCC agonist FPL 64716, the use of which results in very slow deactivation. 
The initial hyperpolarization causes an increase in intracellular $\mathrm{pH}, \mathrm{pH}_{\mathrm{i}}$, which is apparently necessary for subsequent activation of $\mathrm{Ca}^{2+}$ influx (Gonzalez-Martinez et al., 1992). The increase in $\left[\mathrm{K}^{+}\right]_{\mathrm{O}}$ causes an increase in $\left[\mathrm{Ca}^{2+}\right]_{i}$ in capacitated bovine spermatozoa that is sensitive to blockers of VOCCs (Babcock and Pfeiffer, 1987; Florman et al., 1992; Arnoult et al., 1996a). This VOCC-mediated $\mathrm{Ca}^{2+}$ influx, in a similar manner to that in sea urchin spermatozoa, requires a coincident increase in $\mathrm{pH}_{\mathrm{i}}$. Arnoult et al. (1996a) simultaneously measured $\mathrm{pH}_{\mathrm{i}}$ and $\left[\mathrm{Ca}^{2+}\right]_{\mathrm{i}}$ in individual bovine spermatozoa and showed that an increase in $\left[\mathrm{K}^{+}\right]_{\mathrm{O}}$ to $80 \mathrm{mmol} \mathrm{I}^{-1}$ induces $\mathrm{Ca}^{2+}$ influx only in conjunction with a measurable increase in $\mathrm{pH}_{\mathrm{i}}$ (induced by extracellular application of $\mathrm{NH}_{4}^{+}$). Both depolarization and alkalinization occur upon zona pellucida binding, and the increase in $\mathrm{pH}_{\mathrm{i}}$ is mediated by a pertussis toxin-sensitive mechanism (Florman et al., 1992; Arnoult et al., 1996a).

Linares-Hernandes et al. (1998) carried out similar experiments on uncapacitated human spermatozoa, labelled with Fura-2 and $\mathrm{DiSC}_{3}$ to allow simultaneous monitoring of $\left[\mathrm{Ca}^{2+}\right]_{\mathrm{i}}$ and $E_{\mathrm{m}}$. Cells responded to $\mathrm{K}^{+}$with an increase in $\left[\mathrm{Ca}^{2+}\right]_{\mathrm{i}}$ that included an initial transient component (approximately $30 \mathrm{~s}$ ) and a smaller sustained response. Both the transient and sustained components of the $\mathrm{K}^{+}$-induced $\left[\mathrm{Ca}^{2+}\right]_{i}$ increase were dependent upon influx of $\mathrm{Ca}^{2+}$. Alkalinization was not necessary to permit $\mathrm{Ca}^{2+}$ influx, but simultaneous addition of $\mathrm{NH}_{4}{ }^{+}$with $\mathrm{K}^{+}$increased the $\left[\mathrm{Ca}^{2+}\right]_{\mathrm{i}}$ response by approximately $90 \%$. Fifty micromoles per litre of $\mathrm{Ni}^{2+}$ inhibited the transient component, but the sustained component was blocked only partially by $600 \mu \mathrm{mol} \mathrm{Ni} \mathrm{N}^{2+} \mathrm{I}^{-1}$. Fifty micromoles per litre of nifedipine had no effect. The response to the increase in $\left[\mathrm{K}^{+}\right]_{0}$ was enhanced by prior hyperpolarization of $E_{\mathrm{m}}$ (with valinomycin). The estimated value of $E_{\mathrm{m}}$ before application of valinomycin was $-40 \mathrm{mV}$, so this hyperpolarization may have been necessary to release VOCCs in uncapacitated cells from inactivation, as has been proposed for the hyperpolarizing effect of capacitation (Zeng et al., 1995; Florman et al., 1998; Arnoult et al., 1999; see below). Silvestroni et al. (1997) observed an increase in $\left[\mathrm{Ca}^{2+}\right]_{i}$ in human spermatozoa treated with the insecticide lindane. This effect was believed to reflect alteration of the membrane dipole potential, resulting in activation of VOCCs. The effect was reduced by $45 \%$ in the presence of the DHP nicardipine, and was also inhibited by $\mathrm{Cd}^{2+}$.

\section{Electrophysiological studies}

Although there is a range of techniques that can shed light on the expression and activity of ion channels, detailed knowledge of functional expression and biophysical and pharmacological characteristics can be obtained only by direct application of electrophysiological techniques. Despite considerable efforts, it has proved impossible to obtain records of voltage-operated $\mathrm{Ca}^{2+}$ currents from mature spermatozoa. Darszon and colleagues have used insertion of sperm channels into artificial bilayers and have also successfully applied the cell-attached patch clamp technique to osmotically swollen sea urchin and mouse spermatozoa. These technically demanding studies have provided valuable data on expression of various channels, including a $\mathrm{Ca}^{2+}$ channel in sea urchin and mouse spermatozoa that resembles the ryanodine receptor (Darszon et al., 1999). Unfortunately, this approach has provided little information as yet on the expression of VOCCs in these cells. Tiwari-Woodruff and Cox (1995) inserted boar sperm proteins into artificial bilayers and observed a $\mathrm{Ca}^{2+}$ channel that displayed sensitivity to DHP drugs but showed no voltage sensitivity. In humans, there has been only one report of patching (Weyand et al., 1994), in which a cyclic nucleotide gated $\mathrm{Ca}^{2+}$ channel was observed. Shi and colleagues have inserted human sperm proteins in artificial bilayers and observed various channels, including a $\mathrm{Ca}^{2+}$ permeable channel that shows voltage sensitivity (Chan et al., 1997; Ma and Shi, 1999).

An alternative approach has been to apply the patch clamp technique to immature germ cells. As mature spermatozoa are considered to be transcriptionally inactive, all manufacture of proteins by the germ cell must occur before maturity. Therefore, ion channels of the mature cell may be functionally expressed at the immature stage. The first study on mammalian spermatogenic cells was carried out by Hagiwara and Kawa (1984) on cells dissociated from rat seminiferous tubules. These authors observed a tetraethyl ammonium-sensitive $\mathrm{K}^{+}$current and a transient, LVA, T-like VOCC current that increased in density in more mature cells. More recently, this technique has been applied to spermatogenic cells of mice. Similar to the situation in rats, the only VOCCs observed in these studies were LVA, T-like currents (Arnoult et al., 1996b; Santi et al., 1996). Characterization showed that these currents possessed an unusually high sensitivity to DHPs $\left(\mathrm{IC}_{50}\right.$ for nifedipine $=0.4 \mu \mathrm{mol} \mathrm{I-1}$ (Arnoult et al., 1998) or $10 \mu \mathrm{mol}$ $\mathrm{I}^{-1}$ (Santi et al., 1996)) and were blocked by intermediate concentrations of $\mathrm{Ni}^{2+}\left(\mathrm{IC}_{50}=34 \mu \mathrm{mol} \mathrm{I}{ }^{-1}\right.$ (Arnoult et al., 1998) or 100-200 $\mu \mathrm{mol} \mathrm{I^{-1 }}$ (Santi et al., 1996)). The sensitivity of the mouse spermatogenic cell current to channel-specific toxins has been investigated in elongating spermatids (Wennemuth et al., 2000). These authors observed a $38 \%$ blockade of the current after $5 \mathrm{~min}$ exposure to $\omega$-conotoxin GVIA, a toxin considered to be diagnostic for N-type HVA channels (see above). The remaining portion of the current was almost completely blocked by $100 \mathrm{mmol} \mathrm{Ni}^{2+} \mathrm{I}^{-1}$, whereas this dose gave only $50 \%$ block of non-toxin-pretreated currents. These findings indicate that the LVA current of mouse spermatogenic cells is made up of two components that have similar kinetics but different pharmacology, one of which is $\mathrm{Ni}^{2+}$-sensitive, whereas the other shows a sensitivity to $\omega$-conotoxin GVIA that is unlike the T channel. Small, T-like currents have recently been detected in human spermatogenic cells (Jagannathan et al., in press).

In neuronal cells, HVA currents are regulated by a number of mechanisms, many of which are downstream 
Table 1. Molecular studies on the expression of voltage-operated calcium channels in testis and germ cells

\begin{tabular}{|c|c|c|c|}
\hline Tissue & Method & $\alpha_{1}$-Subunit type(s) investigated and result & Reference \\
\hline \multicolumn{4}{|l|}{ Mouse } \\
\hline Testis & RT-PCR & A, B, C, D, E detected (836-240 bp) & Liévano et al., 1996 \\
\hline Germ cells & RT-PCR & $\begin{array}{l}\text { Primarily E detected (240 bp); A (753 bp) C, } \\
\text { G (520 bp) and H (351 bp) also present }\end{array}$ & $\begin{array}{l}\text { Liévano et al., 1996; } \\
\text { Espinosa et al, 1999 }\end{array}$ \\
\hline Germ cells & Northern blot & C detected (data not shown) & Espinosa et al., 1999 \\
\hline Germ cells & Immunostaining & $\mathrm{A}, \mathrm{C}$ detected; $\mathrm{B}, \mathrm{D}$ not detected & Serrano et al., 1999 \\
\hline Spermatozoa & Immunostaining & A, C detected; B,D not detected & Serrano et al., 1999 \\
\hline Spermatozoa & Immunostaining-immunoblot & $\begin{array}{l}\text { A, C, E-detection/regional localization, } \\
\mathrm{B} \text { - detection/regional localization }\end{array}$ & $\begin{array}{l}\text { Westenbroek and } \\
\text { Babcock, 1999; } \\
\text { Wennemuth et al., } 2000\end{array}$ \\
\hline \multicolumn{4}{|l|}{ Rat } \\
\hline Testis & RT-PCR & C detected (full sequence) & Goodwin et al., 1997 \\
\hline Spermatozoa & Immunostaining & L-type detected (antibody raised against $\alpha_{1 S}$ ) & Goodwin et al., 1997 \\
\hline Spermatozoa & In situ RT-PCR & C detected & Goodwin et al., 1997 \\
\hline Testis/spermatozoa & Western blot & L-type detected (antibody raised against $\alpha_{1 S}$ ) & Goodwin etal., 1998 \\
\hline Testis sections & Immunostaining & L-type detected (antibody raised against $\alpha_{1 S}$ ) & Goodwin et al., 2000 \\
\hline Testis sections & In situ RT-PCR & C detected & Goodwin et al., 2000 \\
\hline Testis & RT-PCR & $\begin{array}{l}\text { G (domain IV and C-terminus, domains I-III } \\
\text { not detected) }\end{array}$ & Jacob and Benoff, 2000 \\
\hline $\begin{array}{l}\text { Multi-tissue northern } \\
\text { blot panel }\end{array}$ & Northern blot & G not detected & Perez-Reyes et al., 1998 \\
\hline Testis sections & $\begin{array}{l}\text { Immunostaining, in situ } \\
\text { hybridization }\end{array}$ & $\begin{array}{l}\text { A and B detected, E not detected } \\
\text { (data not shown) }\end{array}$ & Fragale et al., 2000 \\
\hline \multicolumn{4}{|l|}{ Human } \\
\hline Ejaculated spermatozoa & In situ RT-PCR & C detected & Goodwin et al., 2000 \\
\hline Sperm RNA & RT-PCR & G not detected & Jacob and Benoff, 2000 \\
\hline Testis/male germ cells & PCR & $\mathrm{G}$ and $\mathrm{H}$ full sequence & $\begin{array}{l}\text { Jagannathan et al., } \\
2000 a, b \text {, in press }\end{array}$ \\
\hline Testis & In situ hybridization & $\mathrm{G}$ and $\mathrm{H}$ in germ cells and somatic cells & Jagannathan et al., in press \\
\hline $\begin{array}{l}\text { Multi-tissue northern } \\
\text { blot panel }\end{array}$ & Northern blot & G detected (small amounts), I not detected & Monteil et al., 2000a,b \\
\hline Testis & RT-PCR & H detected (489 bp); G and I not detected & Son et al., 2000 \\
\hline
\end{tabular}

effects of neurotransmitters. There have been relatively few reports of regulation of LVA channel currents, although it is clear that such regulation can occur, both in excitable and non-excitable cells (Barrett et al., 1991; Chesnoy-Marchais and Fritsch, 1994; Pemberton et al., 2000). The T-like current of mouse male germ cells is subject to control by tyrosine phosphorylation-dephosphorylation. Dephosphorylation in response to depolarizing prepulses causes an increase in current amplitude (Arnoult et al., 1997). Espinosa et al. (2000) reported that oestradiol exerts a rapid (non-genomic), inhibitory effect on current amplitude, as has been observed in somatic cells (Zhang et al., 1994; Ogata et al., 1996).

\section{Participation of voltage-operated $\mathrm{Ca}^{2+}$ channels in agonist-induced signalling in mammalian spermatozoa and their regulation during capacitation}

Zona pellucida-induced $\mathrm{Ca}^{2+}$ influx

Initial studies in which it was shown that DHPs inhibit the acrosome reaction and the zona pellucida-induced $\left[\mathrm{Ca}^{2+}\right]_{\mathrm{i}}$ response were interpreted as evidence for involvement of L-type VOCCs in transduction of zona pellucida binding (Florman, 1994). Therefore, it was somewhat surprising when the only functional VOCC in mouse spermatogenic cells (even at the elongating spermatid stage) was shown to be an LVA-T-type channel (see above). The $\left[\mathrm{Ca}^{2+}\right]_{\mathrm{i}}$ response to zona pellucida is prolonged and the acrosome reaction occurs some minutes after the start of this response. In contrast, the influx of $\mathrm{Ca}^{2+}$ through $\mathrm{T}$-channels is transient (usually < $500 \mathrm{~ms}$ ). However, comparison of the pharmacological sensitivities of the LVA current of spermatogenic cells and the zona pellucida-induced $\left[\mathrm{Ca}^{2+}\right]_{i}$ increase in mouse spermatozoa shows great similarity (Arnoult et al., 1996b, 1998). Furthermore, the initial response to zona pellucida is a large, brief $\left[\mathrm{Ca}^{2+}\right]_{i}$ 'spike' with kinetics comparable to those of T-currents (Arnoult et al., 1999). Therefore, it appears that a transient $\mathrm{Ca}^{2+}$ influx through the T-type channel seen in patch-clamped spermatogenic cells is an essential, early event in the response to zona pellucida binding. This initial $\left[\mathrm{Ca}^{2+}\right]_{i}$ spike induces a second, sustained $\mathrm{Ca}^{2+}$ influx. Recent evidence indicates that the sustained component of $\mathrm{Ca}^{2+}$ influx is mediated primarily by a store-operated channel (Putney and McKay, 1999), 


\section{Box 2. Equilibrium potentials and the use of $\mathrm{K}^{+}$as a depolarizing stimulus}

For any species of ion, movement across a biological membrane (through open ion channels) is determined by: (i) the concentration gradient (the difference in concentrations of the ion on the two sides of the membrane); and (ii) the electrostatic force (a force exerted on the ion by any difference in electrical potential across the membrane). Hence, the size and sign of the charge on the ion are important.

There will be a value of membrane potential $\left(E_{\mathrm{m}}\right)$ at which these two forces are equal in amplitude but opposite in direction, such that there is no net flux across the membrane. This value of $E_{\mathrm{m}}$ is called the equilibrium potential. Since the ionic species at a membrane vary in both their concentration gradient and their valency, each ion will have its own equilibrium potential $\left(E_{x}\right.$, where $\mathrm{X}$ is the species of ion). Using the intracellular and extracellular concentrations, the equilibrium potential for any ion can be calculated using the Nernst equation:

$$
E_{\mathrm{X}}=\mathrm{R} T / Z \mathrm{~F} * \ln \left([\mathrm{X}]_{\mathrm{O}} /[\mathrm{X}]_{\mathrm{i}}\right)
$$

where $E_{\mathrm{X}}$ is equilibrium potential for ion $\mathrm{X} ; \mathrm{R}$ is the gas constant; $T$ is temperature in degrees absolute; $Z$ is valency of ion $\mathrm{X} ; \mathrm{F}$ is Faraday's constant; and $[\mathrm{X}]_{\mathrm{O}}$ and $[\mathrm{X}]_{\mathrm{i}}$ are the extracellular and intracellular concentrations of the ion $\mathrm{X}$.

If a membrane is permeable to only one ion, then $E_{\mathrm{m}}$ will settle at the equilibrium potential for that ion. Resting cells are normally most permeable to $\mathrm{K}^{+}$and therefore resting potential of the cell is determined primarily by $E_{\mathrm{K}}$ which is typically around $-80 \mathrm{mV}$. However, resting cell membranes also show some permeability to other ions (such as $\mathrm{Na}^{+}$) that have more positive equilibrium potentials. Therefore, resting potential is less negative than $E_{\mathrm{K}^{\prime}}$ the actual value depending on relative permeabilities to $\mathrm{K}^{+}$and to these other ions. Cells can control $E_{\mathrm{m}}$ by opening and closing channels selective for $\mathrm{K}^{+}$or other ions, thus changing the relative contribution of the various equilibrium potentials to determination of $E_{\mathrm{m}}$. In studies in spermatozoa, the $\mathrm{K}^{+}$ionophore valinomycin has been used to render membranes more $\mathrm{K}^{+}$-permeable, thus moving $E_{\mathrm{m}}$ towards $E_{\mathrm{K}}$ (and hyperpolarizing resting cells). A common technique for investigating voltage-operated calcium channels is to depolarize cells by increasing $\left[\mathrm{K}^{+}\right]_{0} . \mathrm{The}^{\mathrm{increased}}$ $\left[\mathrm{K}^{+}\right]_{\mathrm{O}}$ results in a positive shift in $E_{\mathrm{K}}$ (see Nernst equation above), thus acting as a depolarizing stimulus.

activated after depletion of a small $\mathrm{Ca}^{2+}$ store, probably in the acrosome (O'Toole et al., 2000; Jungnickel et al., 2001). Treatment of mouse spermatozoa with an antibody directed against an extracellular region of the store-operated channel Trp2 not only inhibits the sustained component of the zona pellucida-induced $\left[\mathrm{Ca}^{2+}\right]_{i}$ signal but also reduces zona pellucida-induced acrosome reaction by $>75 \%$ (Jungnickel et al., 2001). This finding not only identifies Trp2 as an important component in the $\mathrm{Ca}^{2+}$ influx pathway in the response of mouse spermatozoa to zona pellucida but also demonstrates the pivotal importance of the sustained component of $\mathrm{Ca}^{2+}$ influx for the acrosome reaction. The mechanism of activation of Trp2 is yet to be established. In somatic cells, these channels open in response to depletion of the $\mathrm{Ca}^{2+}$ store in the endoplasmic reticulum (Putney and MacKay, 1999). The signal transduction components required for mobilization of stored $\mathrm{Ca}^{2+}\left(\mathrm{IP}_{3}\right.$ receptors, sarcoplasmicendoplasmic reticulum $\mathrm{Ca}^{2+}$ ATPases (SERCAs), a putative $\mathrm{Ca}^{2+}$ store) are present in rodent and human spermatozoa (Walensky and Snyder, 1995; Dragileva et al., 1999; Kuroda et al., 1999; Rosato et al., 2001) but the emptying of a store upon agonist stimulation has yet to be demonstrated. The mature spermatozoon also possesses a number of HVA VOCCs and so some participation of one or more of these channels in sustained $\mathrm{Ca}^{2+}$ influx cannot be discounted. In hamsters, $10 \mu \mathrm{mol}$ nifedipine $\mathrm{I}^{-1}$, a blocker of L-channels (but also highly effective against the mouse spermatogenic cell T-channel; see above) inhibits the later part of the sustained component of the $\left[\mathrm{Ca}^{2+}\right]_{i}$ signal and strongly inhibits the acrosome reaction (Shirakawa and Miyazaki, 1999). It has not yet been determined whether the mouse model holds good in humans or other mammals. However, solubilized zona pellucida induces a prolonged $\left[\mathrm{Ca}^{2+}\right]_{\mathrm{i}}$ response in populations of human spermatozoa, monitored by fluorimetry (Patrat et al., 2000), and the magnitude of this response is strongly inhibited by pimozide, indicating the involvement of VOCCs.

\section{Progesterone}

The $\left[\mathrm{Ca}^{2+}\right]_{i}$ response to progesterone has been studied primarily in humans and the participation of VOCCs in this process is disputed. Although several laboratories, including our own, have observed strong inhibition of progesteroneinduced acrosome reaction in human spermatozoa by blockers of VOCCs (Shi and Roldan, 1995; O'Toole et al., 1996), there are no unequivocal reports that these drugs can inhibit the progesterone-induced $\left[\mathrm{Ca}^{2+}\right]_{i}$ signal. Similar to the situation in zona pellucida, the response to progesterone involves at least two phases of $\mathrm{Ca}^{2+}$ influx. An initial transient phase (lasting $>1 \mathrm{~min}$ and clearly different from that activated by zona pellucida) is followed by a sustained phase (Kirkman-Brown et al., 2000). Significant effects of VOCC blockers on the amplitude of the $\left[\mathrm{Ca}^{2+}\right]_{\mathrm{i}}$ transient phase occur only with very high, unselective doses (Blackmore et al., 1990; McLaughlin and Ford, 1994). However, a recent study on mouse spermatozoa by Kobori et al. (2000) reported effects of $1 \mu \mathrm{mol}$ pimozide $\mathrm{I}^{-1}$, a dose appropriate for blockade of the mouse spermatogenic cell T-type current (Arnoult et al., 1998), on prolonged responses to progesterone. Fluorimetric studies on the interaction between the effects of progesterone and thapsigargin (commonly used as an activator of storeoperated channels) showed that the response to 
thapsigargin and the progesterone-induced transient were essentially additive (Blackmore, 1993). Effects on the sustained response have proved more difficult to assess.

\section{Regulation of VOCCs during capacitation}

An important aspect of the induction of the acrosome reaction via VOCC activation is that the channels should remain closed until required, to avoid premature $\mathrm{Ca}^{2+}$ influx and the acrosome reaction. Since the ability of agonists to induce $\mathrm{Ca}^{2+}$ influx and the acrosome reaction is poor in uncapacitated cells (Florman et al., 1998; Visconti and Kopf, 1998; Baldi, 2000), it is likely that release of VOCCs from tonic inhibition occurs during capacitation. Evidence from studies in mice indicates that, for LVA VOCCs, this release may be achieved by regulation of the $E_{\mathrm{m}}$. Estimates of $E_{\mathrm{m}}$ in uncapacitated mouse and bovine spermatozoa lie between -10 and $-50 \mathrm{mV}$ (Espinosa and Darszon, 1995; Zeng et al., 1995; Arnoult et al., 1999). LVA channels (believed to be crucial in the response to zona pellucida; see above) will be inactivated at these membrane potentials and therefore will be unable to respond to a depolarizing stimulus (Box 1). The membrane potential in these cells is sensitive to changes in $\left[\mathrm{K}^{+}\right]_{\mathrm{O}^{\prime}}$ indicating that $\mathrm{K}^{+}$permeability contributes to its determination. However, the effect is less than half of that predicted by the Nernst equation (see Box 2), indicating that other conductances, probably unselective cation channels, also contribute to resting potential (Zeng et al., 1995). The membrane potential hyperpolarizes during capacitation of mouse, bovine and human spermatozoa (Zeng et al., 1995; Arnoult et al., 1999; Brewis et al., 2000). In mouse spermatozoa, this hyperpolarization is associated with an increase in the $\left[\mathrm{K}^{+}\right]_{\mathrm{O}}$ sensitivity of $E_{\mathrm{m}}$, indicating that it is the result largely of increased $\mathrm{K}^{+}$permeability (Zeng et al., 1995) and a consequent shift of $E_{\mathrm{m}}$ towards $E_{\mathrm{K}}$ (Box 2). Single cell analysis of $E_{\mathrm{m}}$ in capacitating mouse spermatozoa shows that only those cells that undergo strong hyperpolarization are able to generate the zona pellucida-induced $\mathrm{Ca}^{2+}$ spike (believed to be $\mathrm{Ca}^{2+}$ influx through the LVA VOCC; see above) and carry out the acrosome reaction upon exposure to the zona pellucida (Arnoult et al., 1999). Thus, it appears that LVA VOCCs are maintained in an inactivated state in uncapacitated cells and that membrane hyperpolarization during capacitation releases these channels from inactivation such that they can respond to a depolarizing stimulus provided by an agonist (Fig. 1a).

Darszon and colleagues have described a pH-regulated, inward rectifier $\mathrm{K}^{+}$channel in mouse spermatogenic cells (Gonzalez-Martinez et al., 2001). The increase in $\mathrm{pH}_{\mathrm{i}}$ that occurs during capacitation (Visconti and Kopf, 1998; Baldi, 2000) may activate this channel, contributing at least a part of the enhanced $\mathrm{K}^{+}$permeability that leads to hyperpolarization (Gonzalez-Martinez et al., 2001; Fig. 1a). A second $\mathrm{K}^{+}$channel (slo3) that is sensitive to increased $\mathrm{pH}$ is present in mouse and (probably) human spermatocytes (Schreiber et al., 1998). However, this channel is also strongly voltage-sensitive, and negligible activity is detected at negative membrane voltages (Schreiber et al., 1998).
A third putative mechanism for hyperpolarization of capacitating cells is activation of a $\mathrm{Ca}^{2+}$-activated $\mathrm{K}^{+}$ channel. Injection of rat testis mRNA into Xenopus oocytes results in expression of currents that show strong similarity to maxi-K, $\mathrm{Ca}^{2+}$-activated $\mathrm{K}^{+}$channels of somatic cells. Immunolocalization and RT-PCR showed these channels to be present in spermatogenic cells including spermatozoa (Wu et al., 1998). Such channels may be activated by the increase in $\left[\mathrm{Ca}^{2+}\right]_{i}$ upon capacitation (see below), contributing to hyperpolarization (Fig. 1a).

Regulation of HVA VOCCs during capacitation may also occur, but it seems unlikely that this is achieved entirely, if at all, by membrane potential. Membrane potentials of uncapacitated spermatozoa ( -10 to $-50 \mathrm{mV}$; see above) are sufficient to release a large proportion of L-type $\left(\alpha_{1 C}\right)$ and $\mathrm{P}$ type (probably $\alpha_{1 \mathrm{~A}}$ ) channels from inactivation (Randall, 1998). Both of these channels are present in mouse spermatozoa and possibly germ cells (Table 1). However, HVA channels of somatic cells are known to be regulated by a number of other mechanisms, including G-protein interaction and phosphorylation (Dolphin, 1998; Walker and De Waard, 1998; Zamponi and Snutch, 1998). Potential mechanisms for regulation of VOCCs during capacitation include tyrosine phosphorylation and changes in membrane lipid composition. In mice, capacitation is correlated with increased tyrosine phosphorylation of a subset of sperm proteins. The T-currents of mouse spermatogenic cells can be enhanced by tyrosine dephosphorylation (Arnoult et al., 1997; see above) but there is, as yet, no evidence for regulation of T-channel tyrosine phosphorylation during capacitation. Induction of capacitation in vitro requires inclusion in the medium of serum albumin, which appears to function primarily as a cholesterol acceptor, removing cholesterol from the membrane and increasing membrane fluidity (Visconti and Kopf, 1998; Baldi, 2000). Changes in phospholipid complement and distribution also occur during capacitation (Flesch and Gadella, 2000). Cholesterol can both inhibit (Jennings et al., 1999) and increase (Sen et al., 1992) VOCC currents. However, the increase in $\left[\mathrm{Ca}^{2+}\right]_{i}$ that accompanies capacitation (Visconti and Kopf, 1998; Baldi, 2000) may reflect leakiness of the fluid or disordered cell membrane. Espinosa et al. (2000) observed an increase in the amplitude of mouse spermatogenic cell T-type currents in response to application of serum albumin, but the mechanism by which this effect is achieved does not seem to involve removal of cholesterol from the plasmalemma.

\section{Future directions}

The evidence summarized above indicates that male germ cells express a diverse range of VOCCs. Most of these channels appear to be non-functional in immature cells and therefore it appears that, if the channels possess functional roles, these are likely to be in the mature spermatozoon. The only one of these channels for which a function has been elucidated is the T-type channel, and even here, there 
is strong evidence only in mice. Potential roles for other channels include processes occurring during capacitation, control of hyperactivation and the transduction of signals during interactions with cells of the female tract. Areas for future study should include all of these, as well as elucidation of the mechanisms underlying the acrosome reaction. Progress in the characterization of the various VOCCs in spermatozoa and in the elucidation of the control of $E_{\mathrm{m}}$ will be integral to success in this endeavour.

S. Jagannathan was supported by a grant from West Midlands Regional Research Fund (LORS).

\section{References}

Key references are identified by asterisks.

*Arnoult C, Zeng Y and Florman HM (1996a) ZP3-dependent activation of sperm cation channels regulates acrosomal secretion during mammalian fertilization Journal of Cell Biology 134 637-645

Arnoult C, Cardullo RA, Lemos JR and Florman HM (1996b) Activation of mouse sperm T-type $\mathrm{Ca}^{2+}$ channels by adhesion to the egg zona pellucida Proceedings of the National Academy of Sciences USA 93 13 004-13 009

Arnoult C, Lemos JR and Florman HM (1997) Voltage-dependent modulation of T-type calcium channels by protein tyrosine phosphorylation EMBO Journal 16 1593-1599

Arnoult C, Villaz M and Florman HM (1998) Pharmacological properties of the T-type $\mathrm{Ca}^{2+}$ current of mouse spermatogenic cells Molecular Pharmacology 53 1104-1111

*Arnoult C, Kazam IG, Visconti PE, Kopf GS and Florman HM (1999) Control of the low voltage-activated calcium channel of mouse sperm by egg ZP3 and by membrane hyperpolarization during capacitation Proceedings of the National Academy of Sciences USA 96 6757-6762

Babcock DF and Pfeiffer DR (1987) Independent elevation of cytosolic [Ca $\left.{ }^{2+}\right]$ and $\mathrm{pH}$ of mammalian sperm by voltage-dependent and $\mathrm{pH}$-sensitive mechanisms Journal of Biological Chemistry 262 15 041-15 047

Baldi E, Luconi M, Bonaccorsi L, Muratori M and Forti G (2000) Intracellular events and signaling pathways involved in sperm acquisition of fertilizing capacity and acrosome reaction Frontiers in Bioscience 5 E110-E123

Barratt CLR and Publicover SJ (2001) Interaction between sperm and zona pellucida in male infertility Lancet 358 1660-1662

Barrett PQ, Isales CM, Bollag WB and McCarthy RT (1991) Modulation of $\mathrm{Ca}^{2+}$ channels by atrial natriuretic peptide in the bovine adrenal glomerulosa cell Canadian Journal of Physiology and Pharmacology 69 1553-1560

Birnbaumer L, Ning Q, Olcese R, Tareilus E, Platano D, Constantin J and Stefani E (1998) Structures and functions of calcium channel $\beta$ subunits Journal of Bioenergetics and Biomembranes 30 357-375

Blackmore PF (1993) Rapid non-genomic actions of progesterone stimulate $\mathrm{Ca}^{2+}$ influx and the acrosome reaction in human sperm Cell Signal $\mathbf{5}$ $531-538$

Blackmore PF, Beebe SJ, Danforth DR and Alexander N (1990) Progesterone and 17-hydroxyprogesterone: novel stimulators of calcium influx in human sperm Journal of Biological Chemistry 265 1376-1380

Breitbart H and Spungin B (1997) The biochemistry of the acrosome reaction Molecular Human Reproduction 3 195-202

Brewis IA, Morton IE, Mohammad SN, Browes CE and Moore HD (2000) Measurement of intracellular calcium concentration and plasma membrane potential in human spermatozoa using flow cytometry Journal of Andrology $21238-249$

Catterall WA (1995) Structure and function of voltage-gated ion channels Annual Review of Biochemistry 64 493-531

Chan HC, Zhou TS, Fu WO, Wang WP, Shi YL and Wong PY (1997) Cation and anion channels in rat and human spermatozoa Biochimica et Biophysica Acta 1323 117-129
Chesnoy-Marchais D and Fritsch J (1994) Concentration-dependent modulations of potassium and calcium currents of rat osteoblastic cells by arachidonic acid Journal of Membrane Biology 138 159-170

*Darszon A, Labarca P, Nishigaki T and Espinosa F (1999) lon channels in sperm physiology Physiological Reviews 79 481-510

Dolphin AC (1998) Mechanisms of modulation of voltage-dependent calcium channels by G proteins Journal of Physiology (London) 506 3-11

Dolphin AC, Wyatt CN, Richards J, Beattie RE, Craig P, Lee JH, Cribbs LL, Volsen SG and Perez-Reyes E (1999) The effect of $\alpha 2 \delta$ and other accessory subunits on expression and properties of the calcium channel a1G Journal of Physiology (London) 519 35-46

Dragileva E, Rubinstein S and Breitbart H (1999) Intracellular $\mathrm{Ca}^{2+}-\mathrm{Mg}^{2+}-$ ATPase regulates calcium influx and acrosomal exocytosis in bull and ram spermatozoa Biology of Reproduction 61 1226-1234

Dunlap K and Ikeda S (1998) Receptor-mediated pathways that modulate calcium channels Seminars in Neuroscience 9 198-208

Espinosa F and Darszon A (1995) Mouse sperm membrane potential: changes induced by $\mathrm{Ca}^{2+}$ FEBS Letters 372 119-125

Espinosa F, López-González I, Serrano CJ, Gasque G, DeLa Vega-Beltrán JL, Treviño CL and Darszon A (1999) Anion channel blockers differentially affect T-type $\mathrm{Ca}^{2+}$ currents of mouse spermatogenic cells, $\alpha 1 \mathrm{E}$ currents expressed in Xenopus oocytes and the sperm acrosome reaction Developmetnal Genetics 25 103-114

Espinosa F, López-González I, Muñoz-Garay C, Felix R, DeLa Vega-Beltrán JL, Visconti PE and Darszon A (2000) Dual regulation of the T-type $\mathrm{Ca}^{2+}$ current by serum albumin $\beta$-estradiol in mammalian spermatogenic cells FEBS Letters 475 251-256

Flesch FM and Gadella BM (2000) Dynamics of the mammalian sperm plasma membrane in the process of fertilization Biochimica et Biophysica Acta 1469 197-235

Florman HM (1994) Sequential focal and global elevations of sperm intracellular $\mathrm{Ca}^{2+}$ are initiated by the zona pellucida during acrosomal exocytosis Developmental Biology 165 152-164

Florman HM, Corron ME, Kim TDH and Babcock DF (1992) Activation of voltage-dependent calcium channels of mammalian sperm is required for zona pellucida-induced acrosomal exocytosis Developmental Biology 152 304-314

Florman HM, Arnoult C, Kazam IG, Li C and O'Toole CMB (1998) A perspective on the control of mammalian fertilization by egg-activated ion channels in sperm: a tale of two channels Biology of Reproduction 59 12-16

Fragale A, Aguanno S, Kemp M, Reeves M, Price K, Beattie R, Craig P, Volsen S, Sher E and D'Agostino A (2000) Identification and cellular localisation of voltage-operated calcium channels in immature rat testis Molecular and Cellular Endocrinology 162 25-33

Gao B, Sekido Y, Maximov A et al. (2000) Functional properties of a new voltage-dependent calcium channel $\alpha 2 \delta$ auxiliary subunit gene (CACNA2D2) Journal of Biological Chemistry 27512 237-12 242

Gonzalez-Martinez MT, Guerrero A, Morales E, De la Torre L and Darszon A (1992) A depolarization can trigger $\mathrm{Ca}^{2+}$ uptake and the acrosome reaction when preceded by a hyperpolarization in L. pictus sea urchin sperm Developmental Biology 150 193-202

Gonzalez-Martinez MT, Galindo BE, De la Torre L, Guerrero A, Morales E, Zapata O, Rodriguez E, Florman HM and Darszon A (2001) A sustained increase in intracellular $\mathrm{Ca}^{2+}$ is required for the acrosome reaction in sea urchin sperm Developmental Biology 236 220-229

Goodwin LO, Leeds NB, Hurley IR, Mandel FS, Pergolizzi RG and Benoff S (1997) Isolation and characterization of the primary structure of testisspecific L-type calcium channel: implications for contraception Molecular Human Reproduction 3 255-268

Goodwin LO, Leeds NB, Hurley I, Cooper GW, Pergolizzi RG and Benoff S (1998) Alternative splicing of exons in the alpha1 subunit of the rat testis L-type voltage-dependent calcium channel generates dihydropyridine binding sites Molecular Human Reproduction 4 215-226

Goodwin LO, Karabinus DS, Pergolizzi RG and Benoff S (2000) L-type voltage dependent calcium channel $\alpha 1 \mathrm{C}$ subunit mRNA is present in ejaculated human spermatozoa Molecular Human Reproduction 6 $127-136$ 
Gu Y, Preston MR, El Haj AJ, Hamid J, Zamponi GW, Howl J and Publicover SJ (1999) Osteoblasts derived from load-bearing bones of the rat express both $\mathrm{L}$ - and T-like voltage-operated calcium channels and mRNA for alpha 1C, alpha 1D and alpha 1G subunits Pflugers Archives 438 553-560

Hagiwara S and Kawa K (1984) Calcium and potassium currents in spermatogenic cells dissociated from rat seminiferous tubules Journal of Physiology (London) 356 135-149

Hull MG, Glazener CM, Kelly NJ, Conway DI, Foster PA, Hinton RA, Coulson C, Lambert PA, Watt EM and Desai KM (1985) Population study of causes, treatment, and outcome of infertility British Medical Journal 291 1693-1697

Irvine DS (1998) Epidemiology and aetiology of male infertility Human Reproduction 13 33-44

Jacob A and Benoff S (2000) Full length low voltage-activated ('T-type') calcium $\left(\mathrm{Ca}^{2+}\right)$ channel $\alpha 1 \mathrm{G}$ mRNA is not detected in mammalian testis and sperm Journal of Andrology, March/April Supplement $\mathbf{5 6} 48$

Jagannathan S, Barratt CLR and Publicover J (2000a) Characterisation of alpha $1 \mathrm{H}$, a T-type calcium ion channel from human germ cells European Journal of Neuroscience 12383

Jagannathan S, Punt EL, Ivic A, Zamponi GW, Hamid J, Barratt CLR and Publicover SJ (2000b) Evidence for the expression of $\alpha 1 \mathrm{G}$ (T-type) voltage operated $\mathrm{Ca}^{2+}$ channels in human male germ cells Journal of Andrology, March/April Supplement 10861

Jagannathan S, Punt EL, Gu Y, Arnoult C, Sakkas D, Barratt CLR and Publicover SJ Identification and localization of T-type voltage-operated calcium channel subunit in human male germ cells - expression of multiple isoforms Journal of Biological Chemistry (in press)

Jennings LJ, Xu QW, Firth TA, Nelson MT and Mawe GM (1999) Cholesterol inhibits spontaneous action potentials and calcium currents in guinea pig gallbladder smooth muscle American Journal of Physiology 277 G1017-G1026

Jungnickel MK, Marrero $\mathrm{H}$, Birmbaumer L, Lemos JR and Florman HM (2001) Trp2 regulated $\mathrm{Ca}^{2+}$ entry into mouse sperm triggered by egg ZP3 Nature Cell Biology 3 499-502

Kirkman-Brown JC, Bray C, Stewart PM, Barratt CLR and Publicover SJ (2000) Biphasic elevation of $\left[\mathrm{Ca}^{2+}\right]_{i}$ in individual human spermatozoa exposed to progesterone Developmental Biology 222 326-335

Kobori H, Miyazaki S and Kubawara Y (2000) Characterization of intracellular $\mathrm{Ca}^{2+}$ increase in response to progesterone and cyclic nucleotides in mouse spermatozoa Biology of Reproduction 63 113-120

Krausz C, Bonaccorsi L, Luconi M, Fuzzi B, Criscuoli L, Pellegrini S, Forti G and Baldi E (1995) Intracellular calcium increase and acrosome reaction in response to progesterone in human spermatozoa are correlated with in vitro fertilization Human Reproduction 10 120-124

Kuroda Y, Kaneko S, Yoshimura Y, Nozawa S and Mikoshiba K (1999) Are there inositol 1,4,5-triphosphate (IP3) receptors in human sperm? Life Sciences 65 135-143

*Lacinová L, Klugbauer N and Hofman F (2000) Low voltage activated calcium channels: from genes to function General Physiology and Biophysics 19 121-136

Liévano A, Santi CM, Serrano CJ, Treviño CL, Bellvé AR, Hernandez-Cruz A and Darszon A (1996) T-type $\mathrm{Ca}^{2+}$ channels and $\alpha 1 \mathrm{E}$ expression in spermatogenic cells and their possible relevance to the sperm acrosome reaction FEBS Letters 388 150-154

Linares-Hernandes L, Guzman-Grenfell AM, Hicks-Gomez JJ and Gonzalez-Martinez M (1998) Voltage dependent calcium influx in human sperm assessed by simultaneous optical detection of intracellular calcium and membrane potential Biochimica et Biophysica Acta 1372 $1-12$

Liu DY, Clark GN, Martic M, Garrett C and Baker HWG (2001) Frequency of disordered zona pellucida (ZP)-induced acrosome reaction in infertile men with normal semen analysis and normal spermatozoa-ZP binding Human Reproduction 16 1185-1190

Ma X-H and Shi Y-L (1999) A patch clamp study on reconstituted calcium permeable channels of human sperm plasma membranes Acta Physiologica Sinica 51 571-579

McLaughlin EA and Ford WC (1994) Effects of cryopreservation on the intracellular calcium concentration of human spermatozoa and its response to progesterone Molecular Reproduction and Development 37 241-246

Martin RL, Lee J-H, Cribbs LL, Perez-reyes E and Hanck DA (2000) Mibefradil block of cloned T-type calcium channels Journal of Pharmacology and Experimental Therapeutics 295 302-308

Mintz IM (1994) Block of Ca channels by the spider toxin omega-Aga-IIIA Journal of Neuroscience 14 2844-2853

Mishra SK and Hermsmeyer K (1994) Resting state block and use independence of rat vascular muscle $\mathrm{Ca}^{2+}$ channels by Ro 40-5967 Journal of Pharmacology and Experimental Therapeutics 269 178-183

Monteil A, Chemin J, Bourinet E, Mennessier G, Lory P and Nargeot J (2000a) Molecular and functional properties of the human $\alpha 1 \mathrm{G}$ subunit that forms T-type calcium channels Journal of Biological Chemistry 275 6090-6100

Monteil A, Chemin J, Leuranguer V, Altier C, Mennessier, Bourinet GE, Lory $\mathbf{P}$ and Nargeot J (2000b) Specific properties of T-type calcium channels generated by the human $\alpha 1$ I subunit Journal of Biological Chemistry 27516 530-16 535

Oehninger S, Sueldo C, Lanzendorf S, Mahony M, Burkman LJ, Alexander NJ and Hodgen GD (1994) A sequential analysis of the effect of progesterone on specific sperm functions crucial to fertilization in vitro in infertile patients Human Reproduction 9 1322-1327

Ogata R, Inoue Y, Nakano H, Ito Y and Kitamura K (1996) Oestradiolinduced relaxation of rabbit basilar artery by inhibition of voltagedependent calcium channels through GTP-binding protein British Journal of Pharmacology 117 351-359

O'Toole CMB, Roldan ERS and Fraser LR (1996) Role for $\mathrm{Ca}^{2+}$ channels in the signal transduction pathway leading to acrosomal exocytosis in human spermatozoa Molecular Reproduction and Development 45 204-211

${ }^{*} \mathrm{O}^{\prime}$ Toole CMB, Arnoult C, Darszon A, Steinhardt RA and Florman HM (2000) $\mathrm{Ca}^{2+}$ entry through store-operated channels in mouse sperm is initated by egg ZP3 and drives the acrosome reaction Molecular Biology of the Cell 11 1571-1584

Patrat C, Serres C and Jouannet P (2000) Induction of a sodium influx by progesterone in human spermatozoa Biology of Reproduction 62 1380-1386

Pemberton KE, Hill-Eubanks LJ and Jones SV (2000) Modulation of lowthreshold T-type calcium channels by the five muscarinic receptor subtypes in NIH 3T3 cells Pflugers Archives 440 452-461

Perez-Reyes E, Cribbs LL, Daud A, Lacerda AE, Barclay J, Williamson MP, Fox M, Rees $\mathbf{M}$ and Lee J-H (1998) Molecular characterization of neuronal low-voltage activated T-type calcium channel Nature 391 896-900

Publicover SJ and Barratt CLR (1999) Voltage-operated $\mathrm{Ca}^{2+}$ channels and the acrosome reaction: which channels are present and what do they do? Human Reproduction 14 873-879

Putney JJW and McKay RR (1999) Capacitative calcium entry channels Bioessays 21 38-46

Randall AD (1998) The molecular basis of voltage-gated $\mathrm{Ca}^{2+}$ channel diversity: is it time for T? Journal of Membrane Biology 161 207-213

Rossato M, Di Virgilio F, Rizzuto R, Galeazzi C and Foresta C (2001) Intracellular calcium store depletion and acrosome reaction in human spermatozoa: role of calcium and plasma membrane potential Molecular Human Reproduction 7 119-128

Santi CM, Darszon A and Hernandez A (1996) A dihydropyridine-sensitive T-type $\mathrm{Ca}^{2+}$ current is the main $\mathrm{Ca}^{2+}$ current in mouse primary spermatocytes American Journal of Physiology 40 C1583-C1593

Schreiber M, Wei A, Yuan A, Gaut J, Saito M and Salkoff L (1998) Slo3, a novel $\mathrm{pH}$-sensitive $\mathrm{K}^{+}$channel from mammalian spermatocytes Journal of Biological Chemistry 273 3509-3516

Sen L, Bialecki RA, Smith E, Smith TW and Colucci WS (1992) Cholesterol increases the L-type voltage-sensitive calcium channel current in arterial smooth muscle cells Circulation Research 71 1008-1017

Serrano CJ, Trevino CL, Felix R and Darszon A (1999) Voltage-dependent $\mathrm{Ca}^{2+}$ channel subunit expression and immunolocalization in mouse spermatogenic cells and sperm FEBS Letters 462 171-176

Shi QX and Roldan ERS (1995) Evidence that GABA A-like receptor is involved in progesterone-induced acrosomal exocytosis in mouse spermatozoa Biology of Reproduction 52 373-381 
Shirakawa H and Miyazaki S (1999) Spatiotemporal characterization of intracellular $\mathrm{Ca}^{2+}$ rise during the acrosome reaction of mammalian spermatozoa induced by zona pellucida Developmental Biology 208 70-78

Silvestroni, Fiorini R and Palleschi S (1997) Partition of the organochlorine insecticide lindane into the human sperm surface induces membrane depolarization and $\mathrm{Ca}^{2+}$ influx Biochemistry Journal 321 691-698

Son W-Y, Lee J-H, Lee J-H and Han C-T (2000) Acrosome reaction of human spermatozoa is mainly mediated by $\alpha 1 \mathrm{H}$ T-type calcium channels Molecular Human Reproduction 6 893-897

Stotz SC and Zamponi GW (2001) Structural determinants of fast inactivation of high voltage-activated $\mathrm{Ca}^{2+}$ channels Trends in Neurosciences 24 176-181

Tiwari-Woodruff SK and Cox TC (1995) Boar sperm plasma membrane $\mathrm{Ca}^{2+}$-selective channels in planar lipid bilayers American Journal of Physiology 268 C1284-C1294

Todorovic SM and Lingle CJ (1998) Pharmacological properties of T-type $\mathrm{Ca}^{2+}$ current in adult rat sensory neurons: effects of anticonvuldant and anesthetic agents Journal of Neurophysiology 79 240-252

Tsien RW, Clozel JP and Nargeot J (1998) Low-Voltage-Activated T-type Calcium Channels Adis International, Tattenhall, Chester

Visconti PE and Kopf GS (1998) Regulation of protein phosphorylation during sperm capacitation Biology of Reproduction 59 1-6

Walensky LD and Snyder SH (1995) Inositol 1,4,5-triphosphate receptors selectively localized to the acrosomes of mammalian sperm Journal of Cell Biology 130 857-869

Walker D and De Waard M (1998) Subunit interactions in voltagedependent $\mathrm{Ca}^{2+}$ channels Trends in Neurosciences 21 148-154

Ward CR and Kopf GS (1993) Molecular events mediating sperm activation Developmental Biology 158 9-34

Wennemuth G, Westenbroek RE, Xu T, Hille B and Babcock DF (2000) Cav2.2 and Cav2.3 ( $\mathrm{N}$ - and R-type) $\mathrm{Ca}^{2+}$ channels in depolarizationevoked entry of $\mathrm{Ca}^{2+}$ into mouse sperm Journal of Biological Chemistry $27521210-21217$
Westenbroek RE and Babcock DF (1999) Discrete regional distributions suggest diverse functional roles of calcium channel $\alpha 1$ subunits in sperm Developmetnal Biology 207 457-469

Weyand I, Godde M, Frings S, Weiner J, Müller F, Altenhofen W, Hatt H and Kaupp UB (1994) Cloning and functional expression of a cyclic-nucleotide-gated channel from mammalian sperm Nature $\mathbf{3 6 8}$ 859-863

Williams ME, Washburn MS, Hans M, Urrutia A, Brust PF, Prodanovich P, Harpold MM and Stauderman KA (1999) Structure and functional characterization of a novel human low-voltage activated calcium channel Journal of Neurochemistry 72 791-799

Wu S, Zhang M, Vest PA, Bhattacharjee A, Liu L and Li M (2000) A mibefradil metabolite is a potent intracellular blocker of L-type $\mathrm{Ca}^{2+}$ currents in pancreatic $\beta$-cells Journal of Pharmacology and Experimental Therapeutics 292 939-943

Wu WL, So SC, Sun YP, Zhou TS, Yu Y, Chung YW, Wang XF, Bao YD, Yan YC and Chan HC (1998) Functional expression of a $\mathrm{Ca}^{2+}$-activated $\mathrm{K}^{+}$ channel in Xenopus oocytes injected with RNAs from the rat testis Biochimica et Biophysica Acta 1373 360-365

Yanagimachi R (1994) Mammalian fertilization. In The Physiology of Reproduction 1 189-317 Eds E Knobil and JD Neill. Raven Press, New York

Zamponi GW and Snutch TP (1998) Modulation of voltage-dependent calcium channels by G proteins Current Opinion in Neurobiology 8 351-356

Zamponi GW, Bourinet E and Snutch TP (1996) Nickel block of a family of neuronal calcium channels: subtype- and subunit-dependent action at multiple sites Journal of Membrane Biology 151 77-90

Zeng Y, Clark EN and Floramn HM (1995) Sperm membrane potential: hyperpolarization during capacitation regulates zona pellucidadependent acrosomal secretion Developmetnal Biology 171 554-563

Zhang F, Ram JL, Standley PR and Sowers JR (1994) 17 beta-estradiol attenuates voltage-dependent $\mathrm{Ca}^{2+}$ currents in $\mathrm{A} 7 \mathrm{r}$ vascular smooth muscle cell line American Journal of Physiology 266 C975-C980 